\title{
Drug repurposing to face Covid-19: Celastrol, a potential leading drug capable of inhibiting SARS-CoV-2 replication and induced inflammation
}

Carlos A. Fuzo ${ }^{1}$, Ronaldo B. Martins ${ }^{2}$, Thais F.C. Fraga-Silva ${ }^{3}$, Martin K. Amstalden ${ }^{1}$, Thais Canassa De Leo ${ }^{1}$, Juliano P. Souza ${ }^{2}$, Thais M. Lima ${ }^{2}$, Lucia H. Faccioli ${ }^{1}$, Suzelei C. França ${ }^{4}$, Vania L.D. Bonato ${ }^{3 *}$, Eurico Arruda $^{2 *}$, Marcelo Dias-Baruffi ${ }^{1, \S^{*}}$

${ }^{1}$ Departamento de Análises Clínicas, Toxicológicas e Bromatológicas. Faculdade de Ciências Farmacêuticas de Ribeirão Preto, Universidade de São Paulo, Ribeirão Preto, SP, Brazil.

${ }^{2}$ Departamento de Biologia Celular e Molecular e Bioagentes Patogênicos, Faculdade de Medicina de Ribeirão Preto, Universidade de São Paulo, Ribeirão Preto, SP, Brazil.

${ }^{3}$ Departamento de Bioquímica e Imunologia. Faculdade de Medicina de Ribeirão Preto, Universidade de São Paulo, Ribeirão Preto, SP, Brazil.

${ }^{4}$ Unidade de Biotecnologia, Universidade de Ribeirão Preto, Ribeirão Preto, SP, Brazil.

*These authors contributed equally to this work.

${ }^{\S}$ Corresponding author: Marcelo Dias-Baruffi (mdbaruff@ fcfrp.usp.br)

\begin{abstract}
The global emergence of Covid-19 has caused huge human casualties. Clinical manifestations of the disease vary from asymptomatic to lethal, and the symptomatic form can be associated with cytokine storm and nonhomeostatic inflammatory response. In face of the urgent demand for effective drugs to treat Covid-19, we have searched for candidate compounds using a drug repurposing approach based on in silico analysis followed by biological validation. Here we identified celastrol, a pentacyclic triterpene isolated from Tripterygium wilfordii Hook F - a plant used in traditional Chinese medicine - as one of the best compounds out of 39 repurposed drug candidates. Celastrol reverted gene expression signature from SARS-CoV-2infected cells; bound with high-affinity energy to viral molecular targets such as main protease $\left(\mathrm{M}^{\text {pro }}\right)$ and receptor-biding domain (RBD); inhibited SARS-CoV-2 replication in monkey (Vero and Vero-ACE2) and human (Caco-2 and Calu-3) cell lines; and decreased interleukin-6 (IL-6) secretion in SARS-CoV-2-infected human cell lines. Interestingly, celastrol acted in a concentration-dependent manner, with undetectable signs of cytotoxicity. Therefore, celastrol is a promising lead drug candidate to treat Covid-19 due to its ability to suppress SARS-CoV-2 replication and IL-6 production in infected cells, two critical events in the pathophysiology of this disease.
\end{abstract}

Keywords: Covid-19, SARS-CoV-2, drug repurposing, reverse gene signature, molecular docking, celastrol 


\section{Introduction}

Covid-19 (Coronavirus Disease 2019), caused by the $\beta$-coronavirus SARS-CoV-2 (Severe Acute Respiratory Syndrome Coronavirus 2), was first reported to the World Health Organization in January 2020 after a local pneumonia outbreak of unknown etiology in Wuhan, China ${ }^{1,2}$. SARS-CoV-2 has been rapidly and effectively transmitted from human-to-human and became a worldwide pandemic that affected more than 137 million people in April 20213,4.

The devastating effects of Covid-19 on global public health and economy have demanded urgent efforts to discover potential drug and vaccine candidates to prevent and treat this disease. Many immunization strategies have been studied since the beginning of the pandemic, demonstrating the fast and extraordinary achievement of pharmaceutical companies in the development of vaccines for Covid-19. Although there are 289 vaccine candidates under development, from which 20 were under phase 3 clinical trial in February $2021^{5-}$ ${ }^{7}$, there are many challenges to achieve an efficient global immunization, such as production limitations, efficacy levels, restrictions on use, dosing procedures, storage requirements, price, emergence of SARS-CoV2 mutants, and promotion of durable immunological memory ${ }^{7-12}$.

Despite the availability of effective vaccines, the quick discovery of drugs to prevent and treat SARSCoV-2 infection is a critical demand to face Covid- $19^{13}$. The drug reuse strategy accelerates the discovery of candidate compounds with known activities associated with reducing the SARS-CoV-2 viral load or promoting a better clinical evolution of Covid-19 ${ }^{14,15}$. One aspect of the immunopathology of this disease that stands out is non-hemostatic inflammation associated with cytokine storm involving by several mediators, including interleukin-6 (IL-6), which is a severity biomarker of this illness ${ }^{16-18}$.

In this sense, bioinformatics and computational biology are powerful and multidimensional in silico tools for drug discovery and repurposing of compounds approved or under clinical trial ${ }^{19-22}$. Some of the currently employed strategies to find drugs applicable in Covid-19 have focused on $(i)$ host or virus targets, such as the receptor-binding domain (RBD) present in spike glycoprotein and angiotensin-converting enzyme II (ACE2), which mediate virus-host cell interaction ${ }^{23,24}$; (ii) proteins/enzymes from virus biosynthesis machinery, such as main protease $\left(\mathrm{M}^{\mathrm{pro}}\right)$ and RNA-dependent RNA polymerase $(\mathrm{RdRp})^{25-27}$; and (iii) reversion of the host gene expression signature of SARS-CoV-2-infected cells ${ }^{15,28,29}$. This study used in silico predictions to repurpose drug candidates that could concomitantly reverse the SARS-CoV-2 gene expression induced in host cells, including IL-6, and target proteins/enzymes essential to the SARS-CoV-2 life cycle, followed by biological validation of the best candidate drug repurposed. 


\section{Models and Methods}

\subsection{Identification of signatures from SARS-CoV-2 in vitro infection model and search for drugs with reversed viral infection signature}

The gene expression signature from SARS-CoV-2-infected primary human lung epithelium cell line (NHBE) was obtained from Blanco-Melo and co-authors ${ }^{30}$, by filtering differentially expressed genes (DEGs) after differential expression analysis from independent biological triplicates of SARS-CoV-2 (USAWA1/2020 strain)-infected and mock-treated cells. The signature was constructed based on DEGs with absolute value of fold change in $\log _{2}$ scale greater than $1\left(\left|\log _{2}(\mathrm{FC})\right|>1\right)$, and significance accepted at adjusted $p$-value $\left(p_{\text {adj }}\right)$ smaller than 0.05 ( $\left.p_{\text {adj }}<0.05\right)$, as determined by the Benjamini and Hochberg $(\mathrm{BH}) \operatorname{method}^{31}$.

The obtained signature containing up- and downregulated genes was used to search for drugs with reversed gene expression signature in comparison to viral infection. The best-ranked drugs $\left(Q_{\text {score }}\right)$ from the signatures of small molecule expression profiles in LINCS L1000 dataset ${ }^{32}$ from Characteristic Direction Signatures Search Engine (L1000CDS ${ }^{2}$ ) were listed ${ }^{33}$ (https://amp.pharm.mssm.edu/L1000CDS2/). The signature was submitted to over-representation analysis using Reactome pathways ${ }^{34}$ and clusterProfiler $R^{2}$ package $^{35}$ to find biological pathways that were enriched due to viral infection, within BH adjusted $p$-value < 0.05. The DEGs from enriched pathways were used to construct a biological score ( $\left.B_{\text {score }}\right)$ for each drug ranging from 0 to 1 , where 0 indicated no reversion and 1 indicated total reversion of the main enriched pathways. A weighting factor was calculated for each DEG by multiplying their occurrence by $\mid \log _{2}(\mathrm{FC})$. $B_{\text {score }}$ was the sum of DEG weighting factors and it was normalized by the sum of all weighting factors. The graphical representation of drug signatures data and scores were generated with pheatmap ${ }^{36}$ and ggplot2 packages $^{37}$ in $R$ software ${ }^{38}$.

\subsection{Docking of selected drugs on SARS-CoV-2 protein targets}

The compounds capable of reversing SARS-CoV-2 infection signature (selected in Section 2.1) were submitted to molecular docking on three SARS-CoV-2 protein targets: the catalytic site of $\mathrm{M}^{\text {pro }}$, the RNA binding site of RdRp, and the RBD domain of spike glycoprotein, using multiple structural conformations. Here we used ensemble docking to increase the sampling and avoid unique conformational bias. We have previously generated the representative structures for RBD (unpublished results) using ten centroid clusters obtained from a $600 \mathrm{~ns}$ trajectory, with the aid of molecular dynamics simulation based on the deposited cocrystal RDB/ACE2 structure (PDB id 6M0J) ${ }^{39}$. The multiple structures of $\mathrm{M}^{\text {pro }}$ and RdRp were obtained from Protein Data Bank $(P D B)^{40}$ (Table S1). The heteroatoms were removed from $\mathrm{M}^{\text {pro }}$ and RdRp structures, the resulting structures were repaired, and the energy was minimized with FoldX $X^{41}$. AutoDockTools ${ }^{42}$ was used to prepare drug and protein input structures for docking analysis and grid box definitions (Table S1). Docking analysis was carried out using Autodock Vina ${ }^{43}$ with exhaustiveness parameter equal to 20. Graphical 
representations of energy results were plotted with ggplot $2 \mathrm{R}$ package and molecular model structures were drawn with Pymol $^{44}$ and Discovery Studio Visualizer ${ }^{\circledR}\left(\right.$ version-2020) $^{45}$.

\subsection{The rationale for selecting a predictable candidate lead drug for experimental validation}

In silico analysis guided the selection of a candidate drug for biological validation, considering the drug's ability to reverse the genetic signature of SARS-CoV-2 infection and its binding affinities to molecular viral targets. Briefly, the ten best repurposed drugs were selected based on $Q_{\text {score }}$ values. A compound with high predicted median binding affinity energy for RBD, $\mathrm{M}^{\mathrm{Pro}}$, and $\mathrm{RdRp}$ - and thereby with strong potential to inhibit the functions of these molecular targets - was selected using molecular docking data.

\subsection{Preparation of viral stock}

To obtain SARS-CoV-2 viral stock, clinical isolates (SARS-CoV-2 Brazil/SPBR-02/2020 strain) from RT-PCR-confirmed Covid-19 patients were propagated using monkey Vero CCL-81 cells (kidney), under strict biosafety level 3 (BSL3) conditions. Briefly, for initial viral passages, Vero CCL-81 cells were cultured in Dulbecco minimal essential medium (DMEM) supplemented with 10\% heat-inactivated fetal bovine serum (FBS) and antibiotic/antimycotic mix $(10,000 \mathrm{U} / \mathrm{mL}$ penicillin and $10,000 \mu \mathrm{g} / \mathrm{mL}$ streptomycin). Viral inoculum (1:100 ratio) was added to the cells, and the culture was incubated (48 hours, $37{ }^{\circ} \mathrm{C}, 5 \% \mathrm{CO}_{2}$ humidified atmosphere) in DMEM without FBS but supplemented with antibiotic/antimycotic mix and trypsin-protease inhibitor, L-1-tosylamide-2-phenylethylchloromethyl ketone (TPCK) host cell treatment (1 $\mu \mathrm{g} / \mu \mathrm{L})$ to optimize virus adsorption to the cells ${ }^{46}$. After confirming the cytopathic effects of the viral preparation using an inverted Olympus ix51 microscope, infected Vero CCL-81 cells were detached by scraping, harvested, and centrifuged $(10000 \times g, 10$ minutes, room temperature). The resulting supernatants were stored at $-80{ }^{\circ} \mathrm{C}$ until use. Finally, virus titration was performed on Vero CCL81 cells using standard limiting dilution to determine the $50 \%$ tissue culture infectious dose (TCID50) of viral stock ${ }^{47,48}$.

\subsection{In vitro SARS-CoV-2 infection}

SARS-CoV-2 infection was assessed in vitro in four cell lines: Vero CCL-81, human ACE2transfected Vero CCL-81 (Vero CCL-81-ACE2), human Calu-3 (lung), and human Caco-2 (colon). Cells were seeded into 24 -well plates $(80,000$ cells/well) to ensure $90 \%$ of confluence on the day of inoculation/infection. The four cell lines were infected with SARS-CoV-2 and treated with celastrol. Cells were infected with SARSCoV-2 at multiplicity of infection (MOI) 1.0 in $500 \mu \mathrm{L}$ of infection media composed of DMEM without FBS, $1 \%$ antibiotic/antimycotic mix, and $1 \mu \mathrm{g} / \mu \mathrm{L}$ trypsin-TPCK. After 2 hours of incubation, supernatant containing SARS-CoV-2 was removed and replaced by celastrol $(125,250,500$, and 1,000 $\mathrm{nM})$ or vehicle (0.05\% DMSO) diluted in fresh medium, followed by 48 hours of incubation at $37{ }^{\circ} \mathrm{C}$ and under $5 \% \mathrm{CO}_{2}$. Photomicrographs were taken using the Olympus ix51 inverted microscope and analyzed using the QCapture 
Pro 6.0 software under 200× magnification (QImaging) ${ }^{49}$, in order to examine whether celastrol interfered with SARS-CoV-2 cytopathic effects in Vero CCL-81 cells. The supernatants were collected for RNA extraction and viral load was quantified using a standard curve. All the infections were conducted in technical triplicate.

\subsection{Cell viability}

Cytotoxicity of celastrol (Sigma-Aldrich) to Vero CCL-81, Vero CCL-81-ACE2, Calu-3, and Caco-2 was determined using the Alamar Blue Cell Viability protocol (Thermo Scientific, Waltham, USA), according to the manufacturer's instructions. Briefly, the cells were seeded into a 96-well plate to grow as monolayers and treated with celastrol $(250$ or $1000 \mathrm{nM})$ in DMSO $(0.05 \%)$ or DMSO (5\%, v/v; cell death reference) for 24 hours. Alamar Blue reagent (10\% v/v) was added to the cells, and the plate was incubated at $37^{\circ} \mathrm{C}$, for 4 hours. Median fluorescence intensity was measured using the SpectraMax i-3 (Molecular Devices) microplate reader, with excitation and emission wavelengths set at 530 and $590 \mathrm{~nm}$, respectively. The mean value from the control (untreated cells) was set as $100 \%$, and the viability of cells from each treatment condition was calculated relative to this value, in triplicate.

\subsection{RT-PCR for SARS-CoV-2}

The SARS-CoV-2 genome was quantified using primer-probe sets for N2 and RNAse-P housekeeping gene, following USA-CDC protocols (Table 1$)^{50}$. To determine the genome viral load from in vitro infection assays, N2 and RNAse-P gene were tested by one-step real-time RT-PCR using total nucleic acids extracted with Trizol ${ }^{\circledR}$ (Invitrogen, CA, EUA) from $250 \mu \mathrm{L}$ of culture supernatants. All RT-PCR tests were carried out using the Step-One Plus real-time PCR thermocycler (Applied Biosystems, Foster City, CA, USA). Briefly, $100 \mathrm{ng}$ of RNA were used for genome amplification, mixed with specific primers ( $20 \mu \mathrm{M})$, probe $(5 \mu \mathrm{M})$, and TaqPath 1-Step qRT-PCR Master Mix (Applied Biosystems, Foster City, CA, USA). The following reaction parameters were used: $25^{\circ} \mathrm{C}$ for 2 minutes, $50{ }^{\circ} \mathrm{C}$ for 15 minutes, $95^{\circ} \mathrm{C}$ for 2 minutes, followed by 45 cycles of $95{ }^{\circ} \mathrm{C}$ for 3 seconds and $55^{\circ} \mathrm{C}$ for 30 seconds.

A plasmid standard curve was plotted to determine SARS-CoV-2 viral load. A 944 bp amplicon was inserted into a TA cloning vector (PTZ57R/T CloneJetTM Cloning Kit Thermo Fisher ${ }^{\circledR}$ ), starting from residue 14 of $\mathrm{N}$ gene, which includes all three sets of primers/probe designed by the CDC protocol (N1, N2, and N3). To quantify the amount of virus produced, a tenfold serial dilution of the plasmid was prepared in the range from $10^{6}$ to 1 plasmid copy. The coefficient of determination $\left(R^{2}\right)$ for the plasmid standard curve was 0.999 , with efficiency above $91 \%$ reached using any set of primers/probe ${ }^{51}$.

\subsection{Interleukin 6 quantification}


IL-6 levels were quantified in Caco-2 and Calu-3 cell culture supernatants using the Human DuoSet ELISA assay kit (R\&D Systems, USA), according to the manufacturer's instructions. The IL-6 detection limit was 9.38-1200 pg.mL $\mathrm{mL}^{-1}$.

\subsection{Statistical analysis}

Raw data for viral load from RT-PCR was transformed into log scale, normalized, and analyzed by non-linear regression using dose-response curve fitting and the equation log (inhibitor) versus normalized response with variable slope. All the experimental data are expressed as mean \pm standard error of the mean (SEM), and they were plotted and analyzed using GraphPad Prism 7 software ${ }^{52}$. Statistical significance was analyzed by one-way analysis of variance (ANOVA) followed by Tukey's post-test for multiple comparisons. Differences were considered significant at $P<0.05$. The $P$ values were labeled as $* P<0.05$, ** $P<0.01$, $* * * P<0.001$, and $* * * * P<0.0001$. 


\section{Results}

\subsection{Identification of potential candidates for drug repurposing to treat Covid-19}

We determined the genetic signature of SARS-CoV-2-infected NHBE cells based on transcriptome data reported in the literature ${ }^{30}$. Then, we used $|\log 2(\mathrm{FC})|>1$ and $p_{\text {adj }}<0.05$ as selection criteria, and identified 64 up- and 8 down-regulated DEGs in infected NHBE cells (Table S2). The over-representation analysis of selected DEGs in Reactome pathways annotations indicated the existence of 22 significantly enriched biological pathways (Fig. 1a, Table S3). The top enriched pathways were related to interleukin, chemokine, and interferon signaling, according to literature data ${ }^{30}$, and were closely related to biological pathways involved in SARS-CoV-2 human infection ${ }^{53-56}$.

Considering that the genetic signature described here was composed of DEGs associated with Covid-19 pathophysiology, we searched for candidate drugs that could reverse the genetic signature of NHBE-infected cells using the L1000CDS2 protocol to define the $Q_{\text {score }}$. The top 50 better-scored drug signatures were able to modify the expression pattern of 46 DEGs (42 up-regulated and 4 down-regulated) from the original input of 72 DEGs (Fig. 1b; Table S4). Based on the $Q_{\text {score }}$ values from these 50 drug signatures, a medium value score was defined as 0.26 (Fig. 1c). CGP-60474, a cyclin-dependent kinase inhibitor ${ }^{57}$, exhibited the bestranked $Q_{\text {score }}(0.33)$ : it down-regulated 19 DEGs that were up-regulated by SARS-CoV-2 infection. The second best-ranked $Q_{\text {score }}(0.30)$ was associated with three drugs that modified the expression levels of 17 DEGs induced by SARS-CoV-2: $i$ ) celastrol, a pentacyclic triterpenoid derived from Tripterygium wilfordii Hook F with anti-inflammatory and anti-cancer properties ${ }^{58}$; ii) A443654, a potent inhibitor of all members of the protein kinase B (Akt/PKB) family ${ }^{59}$; and iii) dasatinib, a small-molecule inhibitor of multiple tyrosine kinases $^{60}$ (Fig.1c). In the set of best-ranked drugs by $Q_{\text {score }}$, CGP-60474, celastrol, and A443654 also presented $B_{\text {score }}$ values higher than the mean score of 0.49 (Fig. 1d), suggesting that they are potential reversers of biological pathways related to SARS-CoV-2 infection.

\subsection{Selection of drugs that bind to viral molecular targets (RBD, $M^{\text {pro }}$, and RdRp) among those that reverse SARS-CoV-2-induced genetic signature}

We have searched for candidate drugs with two potential actions: to revert the genetic signature of SARS-CoV-2 infection and interfere with critical events of viral infection. For this purpose, 39 drugs previously identified as reversers of the viral genetic signature were submitted to molecular docking on four regions of three critical viral targets: $i$ ) the catalytic site of $\mathrm{M}^{\text {pro }}$; ii) two sites of RBD, RBD1 and RBD2; and iii) RNA-binding cleft of RdRp (Fig. 2a).

We determined the pose with the highest binding affinity energy $\left(\Delta G_{b i n d}\right.$ in $\left.\mathrm{kcal}^{\mathrm{mol}}{ }^{-1}\right)$ for each ensemble's structures of all selected compounds and viral molecular targets (Fig. 2b). The $\Delta G_{b i n d}$ values ranged from $-9.6 \mathrm{kcal}_{\mathrm{mol}} \mathrm{m}^{-1}$ for the leucine-rich repeat kinase inhibitor XMD- $1150^{61}$ binding to $\mathrm{M}^{\text {pro }}$ to $-4.5 \mathrm{kcal}^{\mathrm{mol}}{ }^{-}$ 
${ }^{1}$ for the histone deacetylase inhibitor vorinostat ${ }^{62}$ binding to RBD2. The ensemble dockings on different conformations led to energetic variations but not to wide dispersion of $\Delta G_{b i n d}$ values, demonstrating that certain drugs maintained their high binding affinity to different conformations of the studied targets.

Celastrol exhibited the most attractive $\Delta G_{\text {bind }}$ median values of energy out of the first ten best-ranked drugs for the viral targets $\left(\mathrm{M}^{\mathrm{pro}}=-7.3, \mathrm{RDB} 1=-6.2\right.$, and $\left.\mathrm{RBD} 2=-6.7 \mathrm{kcal}^{\mathrm{mol}}{ }^{-1}\right)$, and presented the second most attractive $\Delta G_{b i n d}$ median value for $\operatorname{RdRp}\left(-7.8 \mathrm{kcal}^{\mathrm{mol}}{ }^{-1}\right.$ - Fig. $\left.2 \mathrm{~b}\right)$. The chemical pattern of celastroltarget interactions was composed of conventional hydrogen bonds, carbon-hydrogen bonds, Pi interactions, and van der Waals interactions that favored a more attractive binding affinity of celastrol to $\mathrm{M}^{\mathrm{pro}}, \mathrm{RBD} 1$, and RBD2 with $\Delta G_{\text {bind }}$ equal to $-8.7,-6.8$, and $-8.1 \mathrm{kcal} \mathrm{mol}^{-1}$, respectively (Fig. 3). The celastrol binding to $\mathrm{M}^{\text {pro }}$ catalytic site was mediated by the sigma Pi interaction among the E-ring $\mathrm{O}_{2}$, His 41 and hydrogen bound in Thr25, and $\mathrm{OH}$ group of A-ring C3. The mean atomic distance between the B-ring C6 and the Cys145 sulfur atom - a critical amino acid of the $\mathrm{M}^{\text {pro }}$ catalytic site - was $0.63 \mathrm{~nm}$ (range: 0.43-1.33 nm) (Fig. 3), suggesting an appropriate geometry to the formation of a covalent bond. In addition, celastrol exhibited one of the highest $B_{\text {score }}$ values (0.53) among the 39 drugs analyzed, indicating that this compound had a great potential to revert the genetic signature of SARS-CoV-2 infection (Fig. 1d). Of note, the protein kinase inhibitor WZ-4-145 ${ }^{63}$ displayed the best $\Delta G_{\text {bind }}\left(-8.3 \mathrm{kcal}_{\mathrm{mol}} \mathrm{m}^{-1}\right)$ to $\mathrm{RdRp}$ due to a myriad combination of interactions, including conventional hydrogen bonds, alkyl, and Pi interactions (Fig. 2b and Fig. 3). Some drugs with high affinity to the studied targets, such as XMD-1150 to $\mathrm{M}^{\mathrm{pro}}$ and KIN001-265 to RBD1, RBD2, and RdRp, were poorly ranked in reverse signature repurposing but they could be relevant due to their predicted binding abilities. The $\Delta G_{b i n d}, Q_{\text {Score }}$, and $B_{\text {score }}$ values of celastrol supported its selection to biological validation.

\subsection{Celastrol inhibits SARS-CoV-2 cellular propagation and IL-6 secretion by infected cells without cytopathic effect in vitro}

\subsubsection{Celastrol reduces SARS-CoV-2 viral load on infected cells}

In silico analysis indicated that celastrol is a potential drug candidate to treat Covid-19 due to its ability to reverse the genetic signature of SARS-CoV-2 infection and interact with high affinity with critical molecular viral targets. This in silico prediction was validated using in vitro SARS-CoV-2 cell propagation inhibition assays. Celastrol significantly reduced viral load in two monkey cell lines (Vero CCL-81 and Vero CCL-81-ACE2) and two human cell lines (Caco-2 and Calu-3) (Figure 4). Interestingly, the anti-SARS-CoV2 effect of celastrol was concentration-dependent and it drastically inhibited viral replication in Vero CCL81, Vero CCL-81-ACE2, and Calu-3 cells when tested at $1000 \mathrm{nM}$.

To examine whether cytotoxicity mediated the anti-viral effect of celastrol, we determined the cell viability of the four cell lines treated with celastrol at two concentrations, $250 \mathrm{nM}$ and $1000 \mathrm{nM}$, which promoted its minimal and maximum anti-viral action in human cell lines, respectively. Celastrol-treated cells and the negative control had similar viability levels, of nearly 100\% (Fig. 5a-d). Treatment with 5\% DMSO 
(positive control) decreased cell viability by more than $80 \%$. Celastrol also significantly reduced SARS-CoV2 cytopathic effect in a concentration-dependent manner (Fig. S1).

\subsubsection{Celastrol lowers IL-6 production in SARS-CoV-2-infected human cell lines}

SARS-CoV-2 infection of human cell lines increased gene expression of inflammatory mediators, such as IL-6, as demonstrated by in silico analysis, and celastrol reversed this effect (Fig. 1). To test this prediction, we determined IL-6 levels in the supernatant of SARS-CoV-2-infected cells treated or not with celastrol. This compound at 500 and $1000 \mathrm{nM}$ significantly decreased IL-6 production by Caco-2-infected cells, and at 1000 $\mathrm{nM}$ it decreased IL-6 production by Calu-3-infected cells (Fig.6). Curiously, Caco-2-infected cells produced around ten-fold lower IL-6 levels than Calu-3-infected cells. This phenomenon may be associated with the lower viral load in culture supernatants of Caco-2 cells, as compared with samples from Calu-3 cells (Fig. $4 \mathrm{c}, \mathrm{d})$. 


\section{Discussion}

Here, we identified 39 potential repurposed drug candidates for Covid-19 treatment based on in silico prediction of their abilities to revert the genetic signature of SARS-CoV-2-infected cells and bind with high affinity to viral targets. One of the in silico best-ranked candidates was celastrol, which was also able to inhibit the virion particles release and IL-6 secretion by SARS-CoV-2-infected cells. This combination between computational and experimental analyzes validated the literature predictions about the potential use of celastrol to face Covid-19 based on its anti-inflammatory and antiviral properties ${ }^{64,65}$. Other in silico bestranked candidates with antitumor, kinase-inhibition, and anti-inflammatory properties have been proposed to treat Covid-19, such as CGP-60474, A-443654, alvocidib, canertinib, dasatinib, vorinostat, and geldanamycin ${ }^{29,66-68}$.

The perturbed gene expression during SARS-CoV-2 infection in vitro modulates biological processes of clinical relevance, such as cytokine-mediated gene expression, type I interferon pathways, and antiviral responses as detected in our current analysis and literature ${ }^{30}$. As expected, genes of pro-inflammatory cytokines (IL-1 $\beta$, IL-6, IL-8, TNF- $\alpha$, and others), chemokines (CXCL1 and CCL20), and some NF- $\kappa$ B pathway components were up-regulated, and are related to the severity and progression of Covid-1955,69-72.

Celastrol was the second best-ranked drug able to reverse the genetic signature in SARS-CoV-2infected cells, in agreement with its reported anti-inflammatory properties ${ }^{73}$. This triterpene also dampens HIV-1 Tat-induced inflammatory responses, inhibits the production of proinflammatory chemokines, such as CXCL10, IL-8, and MCP-1 (YOUN et al., 2014), and suppresses replication of Dengue virus serotype 1-4 by promoting IFN- $\alpha$ expression and stimulating downstream antiviral responses ${ }^{74}$. Celastrol suppresses the production of cytokines during cytokine storm and of chemokines related to worse disease prognosis, such as IL-8, IL-6, CXCL1, and CCL20 ${ }^{75-77}$, lowers the levels of anti-inflammatory markers ${ }^{78}$, and stimulates type I interferon production and expression of interferon-stimulated genes against Dengue virus infection ${ }^{74}$.

Considering that the direct interaction between celastrol and viral targets can mediate its antiviral activity $^{79,80}$, we demonstrated its ability to bind $\mathrm{M}^{\text {pro }}, \mathrm{RBD} 1, \mathrm{RDB} 2$, and RdRp, which are essential to the viral life cycle ${ }^{19,24-27}$. A previous study has described the celastrol interaction with the catalytic site of the SARS$\mathrm{CoV} \mathrm{M}^{\text {pro } 81}$. Docking simulations on the catalytic site of $\mathrm{M}^{\text {pro }}$ revealed that the celastrol binding energy was higher than that of most compounds tested here. Our models suggested that the high binding affinity of celastrol to $\mathrm{M}^{\text {pro }}$ involved the sigma $\mathrm{Pi}$ interaction between the E-ring $\mathrm{O}_{2}$ and His41, associated with the hydrogen bond between Thr25 and the hydroxyl group of A-ring C3, in agreement with literature reports ${ }^{79,80}$. In addition, our atomic distance analysis suggested that B-ring C6 interacted with Cys 145 - a critical amino acid of $\mathrm{M}^{\text {pro }}$ catalytic site - by forming a Michael's adduct; this inhibition mechanism of celastrol was also proposed in other molecular targets ${ }^{82,83}$. The anti-inflammatory activity of celastrol is associated with downregulation of NF-kB pathway mediated by suppression of IKK activation (SETHI et al., 2006), probably due to the formation of Michael's adduct between its quinone methide and Cys 179 from IKK ${ }^{80,84}$. In silico studies have reported that other quinone derivatives exhibit antiviral properties associated with the ability to form 
Michael's adduct ${ }^{85}$, such as the glucocorticoids methylprednisolone and dexamethasone used to treat severe Covid-19 patients $^{86,87}$.

Next, we demonstrated that celastrol exerted antiviral and anti-inflammatory effect in vitro, which biologically validated our in silico findings here reported. Celastrol (250 to $1000 \mathrm{nM}$ ) reduced the viral progeny of SARS-CoV-2 in Vero CCL-81 and Vero CCL-81-ACE2 cells, as well as in the pulmonary and intestinal epithelial human cell lines Calu-3 and Caco-2, respectively. The anti-viral effect of celastrol is selective, since it does not inhibit influenza A virus replication (H1N1; PR8) in Madin-Darby Canine kidney cell line (MDCK) when tested at 150 to $600 \mathrm{nM}^{88}$, but it significantly reduces HIV replication in U937 cells at $150 \mathrm{nM}^{89}$, as we found for SARS-CoV-2.

As expected, the reuse of transcriptome data from SARS-CoV-2-infected NHBE cells, a normal human bronchial epithelial cell line, evidenced enriched biological pathways associated with non-hemostatic inflammation, including upregulation of the IL-6 gene expression. A recent review paper from our team has reported the relationship between serum IL-6 levels and different outcomes of Covid-19 patients ${ }^{90}$ : compared with severe patients, critical and mild patients have higher and lower IL-6 levels, respectively; and nonsurvivors exhibit significantly higher IL-6 levels than survivors with Covid-19. In vitro assays using Calu-3, A549, and NHBE cells have confirmed that SARS-CoV-2 infection induces IL-6 production ${ }^{30}$. As IL-6 production is increased in both Covid-19 patients and in vitro SARS-CoV-2 infection models, we examined whether celastrol altered the levels of this cytokine in vitro. Celastrol at 500 and $1000 \mathrm{nM}$ down-regulated the infection-induced IL-6 production in Caco-2 and Calu-3 cells, and such effect was associated with the decreased SARS-CoV-2 load. The inhibition of IL-6 production by celastrol could be associated or not with the reduced viral load observed on infected cells. The modulatory effect of celastrol over IL-6 release has been described in vitro under sterile inflammatory conditions ${ }^{91}$. In addition, this triterpene down-regulates IL-6 secretion and gene expression in PC-3 prostate carcinoma cells, in a NF- $\kappa \mathrm{B}-$ dependent manner ${ }^{92}$, suppresses LPS-induced IL-6 production in RAW264.7 macrophages $^{93}$, and decreases the IL-6 concentration and mRNA expression but not the virus title and mRNA expression in influenza A-infected MDCK cells ${ }^{88}$. Of note, celastrol reduced lung injury and the release of proinflammatory mediators into the pulmonary airways, including IL-6 production, in an experimental model of acute respiratory distress syndrome (ARDS) ${ }^{94}$.

Our findings demonstrated that celastrol was able to reduce both SARS-CoV-2 viral load and IL-6 production in two human cell lines, suggesting that this compound exerts anti-SARS-CoV-2 effects of clinical relevance to face the current pandemic. Several pharmacological applications of celastrol are associated with Covid-19 severity, including comorbidities such as obesity, diabetes, hypertension, and metabolic syndrome ${ }^{95-}$ ${ }^{98}$, and pathological events such as non-homeostatic production of pro-inflammatory cytokines, thrombus generation, and formation of neutrophil extracellular traps ${ }^{99-101}$. Celastrol is currently under clinical trials to treat a variety of diseases, including different types of cancer, neurodegenerative disorders, and inflammatory conditions such as rheumatoid arthritis, psoriasis, and Crohn's disease ${ }^{102-106}$. 
Despite its potential therapeutic effects, there are still some limitations to the use of celastrol, such as its low solubility that results in poor bioavailability, in vitro and in vivo toxicity, and adverse effects that remain to be evaluated ${ }^{107,108}$. Celastrol was not cytotoxic to all cell lines tested herein, even at the highest concentration $(1000 \mathrm{nM})$, corroborating other reports using Caco-2 cells ${ }^{109}$. At $1000 \mathrm{nM}$, this compound reduced the SARS-CoV-2-cytopathic effect on Vero CCL-81 cells. A recent study using a mouse model of acute toxicity has demonstrated that celastrol is safe even when orally administered at a high dose $(62.5 \mathrm{mg} / \mathrm{kg}$ body weight $)^{110}$. Intraperitoneal administration of celastrol $(0.25 \mathrm{mg} / \mathrm{kg}$ body weight $)$ increases the gamma irradiated-mice survival rate by around $70^{78}$. To surpass celastrol toxicity, solubility, and pharmacokinetic issues, several pharmaceutical approaches have been proposed, such as nanoencapsulation, liposomes, and sugar-silica nanoparticles ${ }^{111-113}$. Celastrol has been considered a lead drug for several human illnesses, but its toxicity to humans remains to be determined ${ }^{64,73,114}$.

To the best of our knowledge, the present study is the pioneer to use the combination between bioinformatic tools and biological approaches to demonstrate that celastrol inhibits the SARS-CoV-2 replication in non-human and human cell lines, and down-regulates IL-6 secretion from infected-human cell lines, reinforcing that celastrol is a potential repurposed drug to treat Covid-19. 
bioRxiv preprint doi: https://doi.org/10.1101/2021.04.20.439992; this version posted April 20, 2021. The copyright holder for this preprint (which was not certified by peer review) is the author/funder. All rights reserved. No reuse allowed without permission.

\section{Acknowledgements}

We are thankful to the Brazilian National Council for Scientific and Technological Development (CNPq, grant \#312606/2019-2 to M.D.B.), the Coordination for the Improvement of Higher Educational Personnel (CAPES, Finance Code 001), and the São Paulo Research Foundation (FAPESP, grant \#20/052700 to V.L.D.B.).

\section{Competing Interests}

The authors declare no competing interests.

\section{References}

1. World Health Organization. Novel Coronavirus - China.

2. Zhu N., Zhang D., Wang W., Li X., Yang B., Song J., et al. A Novel Coronavirus from Patients with Pneumonia in China, 2019. N Engl J Med 2020;382(8):727-33. Doi: 10.1056/NEJMoa2001017.

3. Dong E., Du H., Gardner L. An interactive web-based dashboard to track COVID-19 in real time. Lancet Infect Dis 2020;3099(20):19-20. Doi: 10.1016/S1473-3099(20)30120-1.

4. $\quad$ Li Q., Guan X., Wu P., Wang X., Zhou L., Tong Y., et al. Early transmission dynamics in Wuhan, China, of novel coronavirus-infected pneumonia. N Engl J Med 2020;382(13):1199-207. Doi: 10.1056/NEJMoa2001316.

5. Polack FP., Thomas SJ., Kitchin N., Absalon J., Gurtman A., Lockhart S., et al. Safety and Efficacy of the BNT162b2 mRNA Covid-19 Vaccine. N Engl J Med 2020. Doi: 10.1056/NEJMoa2034577.

6. Voysey M., Clemens SAC., Madhi SA., Weckx LY., Folegatti PM., Aley PK., et al. Safety and efficacy of the ChAdOx1 nCoV-19 vaccine (AZD1222) against SARS-CoV-2: an interim analysis of four randomised controlled trials in Brazil, South Africa, and the UK. Lancet 2020. Doi: 10.1016/S0140-6736(20)32661-1.

7. Wouters OJ., Shadlen KC., Salcher-Konrad M., Pollard AJ., Larson HJ., Teerawattananon Y., et al. Challenges in ensuring global access to COVID-19 vaccines: production, affordability, allocation, and deployment. Lancet (London, England) 2021;397(10278):1023-34. Doi: 10.1016/S0140-6736(21)00306-8.

8. Thomson EC., Rosen LE., Shepherd JG., Spreafico R., da Silva Filipe A., Wojcechowskyj JA., et al. The circulating SARS-CoV-2 spike variant N439K maintains fitness while evading antibody-mediated immunity. BioRxiv 2020:2020.11.04.355842. Doi: 10.1101/2020.11.04.355842.

9. Wang W., Wu Q., Yang J., Dong K., Chen X., Bai X., et al. Global, regional, and national estimates of target population sizes for covid-19 vaccination: descriptive study. BMJ 2020;371:m4704. Doi: 10.1136/bmj.m4704.

10. Fontanet A., Autran B., Lina B., Kieny MP., Karim SSA., Sridhar D. SARS-CoV-2 variants and ending the COVID-19 pandemic. Lancet 2021. Doi: 10.1016/S0140-6736(21)00370-6.

11. Baric RS. Emergence of a Highly Fit SARS-CoV-2 Variant. N Engl J Med 2020;383(27):2684-6. Doi: 10.1056/NEJMcibr2032888.

12. Teijaro JR., Farber DL. COVID-19 vaccines: modes of immune activation and future challenges. Nat Rev Immunol 2021. Doi: 10.1038/s41577-021-00526-x.

13. Atzrodt CL., Maknojia I., McCarthy RDP., Oldfield TM., Po J., Ta KTL., et al. A Guide to COVID-19: a global pandemic caused by the novel coronavirus SARS-CoV-2. FEBS J 2020;287(17):3633-50. Doi: 10.1111/febs.15375.

14. Kiplin Guy R., Dipaola RS., Romanelli F., Dutch RE. SCIENCE sciencemag.org 2020. Doi: 10.1038/s41586.

15. Galindez G., Matschinske J., Rose TD., Sadegh S., Salgado-Albarrán M., Späth J., et al. Lessons from the COVID-19 pandemic for advancing computational drug repurposing strategies. Nat Comput Sci 2021;1(1):33-41. Doi: 10.1038/s43588-020-00007-6.

16. Tay MZ., Poh CM., Rénia L., MacAry PA., Ng LFP. The trinity of COVID-19: immunity, inflammation and intervention. Nat Rev Immunol 2020;20(6):363-74. Doi: 10.1038/s41577-020-0311-8.

17. Hadjadj J., Yatim N., Barnabei L., Corneau A., Boussier J., Smith N., et al. Impaired type I interferon activity and inflammatory responses in severe COVID-19 patients. Science (80- ) 2020. Doi: 10.1126/science.abc6027.

18. Han H., Ma Q., Li C., Liu R., Zhao L., Wang W., et al. Profiling serum cytokines in COVID-19 patients reveals IL-6 and IL-10 are disease severity predictors. Emerg Microbes Infect 2020;9(1):1123-30. Doi: 10.1080/22221751.2020.1770129.

19. Zhou Y., Hou Y., Shen J., Huang Y., Martin W., Cheng F. Network-based drug repurposing for novel coronavirus 2019nCoV/SARS-CoV-2. Cell Discov 2020;6(1):14. Doi: 10.1038/s41421-020-0153-3.

20. Pawar AY. Combating Devastating COVID -19 by Drug Repurposing. Int J Antimicrob Agents 2020:105984. Doi: https://doi.org/10.1016/j.ijantimicag.2020.105984.

21. Lotfi Shahreza M., Ghadiri N., Mousavi SR., Varshosaz J., Green JR. A review of network-based approaches to drug repositioning. Brief Bioinform 2018;19(5):878-92. Doi: 10.1093/bib/bbx017. 
bioRxiv preprint doi: https://doi.org/10.1101/2021.04.20.439992; this version posted April 20, 2021. The copyright holder for this preprint (which was not certified by peer review) is the author/funder. All rights reserved. No reuse allowed without permission.

22. Shameer K., Readhead B., Dudley JT. Computational and experimental advances in drug repositioning for accelerated therapeutic stratification. Curr Top Med Chem 2015;15(1):5-20. Doi: 10.2174/1568026615666150112103510.

23. Gordon DE., Jang GM., Bouhaddou M., Xu J., Obernier K., White KM., et al. A SARS-CoV-2 protein interaction map reveals targets for drug repurposing. Nature 2020. Doi: 10.1038/s41586-020-2286-9.

24. Hanson QM., Wilson KM., Shen M., Itkin Z., Eastman RT., Shinn P., et al. Targeting ACE2-RBD interaction as a platform for COVID19 therapeutics: Development and drug repurposing screen of an AlphaLISA proximity assay. ACS Pharmacol Transl Sci 2020;3(6):1352-60. Doi: DOI: 10.1021/acsptsci.0c00161.

25. Jin Z., Du X., Xu Y., Deng Y., Liu M., Zhao Y., et al. Structure of Mpro from COVID-19 virus and discovery of its inhibitors. Nature 2020. Doi: 10.1038/s41586-020-2223-y.

26. Ton A-T., Gentile F., Hsing M., Ban F., Cherkasov A. Rapid Identification of Potential Inhibitors of SARS-CoV-2 Main Protease by Deep Docking of 1.3 Billion Compounds. Mol Inform 2020;n/a(n/a). Doi: 10.1002/minf.202000028.

27. Elfiky AA. Ribavirin, Remdesivir, Sofosbuvir, Galidesivir, and Tenofovir against SARS-CoV-2 RNA dependent RNA polymerase (RdRp): A molecular docking study. Life Sci 2020;253:117592. Doi: https://doi.org/10.1016/j.lfs.2020.117592.

28. Riva L., Yuan S., Yin X., Martin-Sancho L., Matsunaga N., Burgstaller-Muehlbacher S., et al. A Large-scale Drug Repositioning Survey for SARS-CoV-2 Antivirals. BioRxiv 2020:2020.04.16.044016. Doi: 10.1101/2020.04.16.044016.

29. Belyaeva A., Cammarata L., Radhakrishnan A., Squires C., Yang KD., Shivashankar G V., et al. Causal network models of SARS-CoV-2 expression and aging to identify candidates for drug repurposing. Nat Commun 2021;12(1):1024. Doi: 10.1038/s41467-021-21056-Z.

30. Blanco-Melo D., Nilsson-Payant BE., Liu WC., Uhl S., Hoagland D., Møller R., et al. Imbalanced Host Response to SARS-CoV-2 Drives Development of COVID-19. Cell 2020. Doi: 10.1016/j.cell.2020.04.026.

31. Benjamini Y., Hochberg Y. Controlling the False Discovery Rate: A Practical and Powerful Approach to Multiple Testing. J R Stat Soc Ser B 1995;57(1):289-300.

32. Subramanian A., Narayan R., Corsello SM., Peck DD., Natoli TE., Lu X., et al. A Next Generation Connectivity Map: L1000 Platform and the First 1,000,000 Profiles. Cell 2017;171(6):1437-1452.e17. Doi: 10.1016/j.cell.2017.10.049.

33. Duan Q., Reid SP., Clark NR., Wang Z., Fernandez NF., Rouillard AD., et al. L1000CDS2: LINCS L1000 characteristic direction signatures search engine. Npj Syst Biol Appl 2016;2(1):16015. Doi: 10.1038/npjsba.2016.15.

34. Jassal B., Matthews L., Viteri G., Gong C., Lorente P., Fabregat A., et al. The reactome pathway knowledgebase. Nucleic Acids Res 2020;48(D1):D498-503. Doi: 10.1093/nar/gkz1031.

35. Yu G., Wang L-G., Han Y., He Q-Y. clusterProfiler: an R Package for Comparing Biological Themes Among Gene Clusters. Omi A J Integr Biol 2012;16(5):284-7. Doi: 10.1089/omi.2011.0118.

36. Kolde R. Implementation of heatmaps that offers more control over dimensions and appearance 2019.

37. Wickham H. ggplot2: Elegant Graphics for Data Analysis, Springer-Verlag New York; 2016.

38. R Core Team. R: A Language and Environment for Statistical Computing 2019.

39. Lan J., Ge J., Yu J., Shan S., Zhou H., Fan S., et al. Structure of the SARS-CoV-2 spike receptor-binding domain bound to the ACE2 receptor. Nature 2020. Doi: 10.1038/s41586-020-2180-5.

40. Berman HM., Westbrook J., Feng Z., Gilliland G., Bhat TN., Weissig H., et al. The Protein Data Bank. Nucleic Acids Res 2000;28(1):235-42.

41. Schymkowitz J., Borg J., Stricher F., Nys R., Rousseau F., Serrano L. The FoldX web server: an online force field. Nucleic Acids Res 2005;33(suppl_2):W382-8. Doi: 10.1093/nar/gki387.

42. Morris GM., Huey R., Lindstrom W., Sanner MF., Belew RK., Goodsell DS., et al. AutoDock4 and AutoDockTools4: Automated docking with selective receptor flexibility. J Comput Chem 2009;30(16):2785-91. Doi: 10.1002/jcc.21256.

43. Trott O., Olson AJ. AutoDock Vina: improving the speed and accuracy of docking with a new scoring function, efficient optimization, and multithreading. J Comput Chem 2010;31(2):455-61. Doi: 10.1002/jcc.21334.

44. Schrodinger LLC. The PyMOL Molecular Graphics System, Version 1.8, 2015.

45. BIOVIA DS. Discovery Studio Visualizer 2020.

46. Banerjee A., Nasir JA., Budylowski P., Yip L., Aftanas P., Christie N., et al. Isolation, Sequence, Infectivity, and Replication Kinetics of Severe Acute Respiratory Syndrome Coronavirus 2. Emerg Infect Dis 2020;26(9):2054-63. Doi: 10.3201/eid2609.201495.

47. REED LJ., MUENCH H. A SIMPLE METHOD OF ESTIMATING FIFTY PER CENT ENDPOINTS12. Am J Epidemiol 1938;27(3):493-7. Doi: 10.1093/oxfordjournals.aje.a118408.

48. Harcourt J., Tamin A., Lu X., Kamili S., Sakthivel SK., Murray J., et al. Severe Acute Respiratory Syndrome Coronavirus 2 from Patient with Coronavirus Disease, United States. Emerg Infect Dis 2020;26(6):1266-73. Doi: 10.3201/eid2606.200516.

49. Kang CK., Seong M-W., Choi S-J., Kim TS., Choe PG., Song SH., et al. In vitro activity of lopinavir/ritonavir and hydroxychloroquine against severe acute respiratory syndrome coronavirus 2 at concentrations achievable by usual doses. Korean J Intern Med 2020;35(4):782-7. Doi: 10.3904/kjim.2020.157. 
bioRxiv preprint doi: https://doi.org/10.1101/2021.04.20.439992; this version posted April 20, 2021. The copyright holder for this preprint (which was not certified by peer review) is the author/funder. All rights reserved. No reuse allowed without permission.

50. Lu X., Wang L., Sakthivel S., Whitaker B., Murray J., Kamili S., et al. US CDC Real-Time Reverse Transcription PCR Panel for Detection of Severe Acute Respiratory Syndrome Coronavirus 2. Emerg Infect Dis J 2020;26(8):1654. Doi: 10.3201/eid2608.201246.

51. Martins RB., Castro IA., Pontelli M., Souza JP., Lima TM., Melo SR., et al. SARS-CoV-2 Inactivation by Ozonated Water: A Preliminary Alternative for Environmental Disinfection. Ozone Sci Eng 2020:1-4. Doi: 10.1080/01919512.2020.1842998.

52. Inc. GS. GraphPad Prism 7.0 2016.

53. Del Valle DM., Kim-Schulze S., Huang H-H., Beckmann ND., Nirenberg S., Wang B., et al. An inflammatory cytokine signature predicts COVID-19 severity and survival. Nat Med 2020;26(10):1636-43. Doi: 10.1038/s41591-020-1051-9.

54. Desai N., Neyaz A., Szabolcs A., Shih AR., Chen JH., Thapar V., et al. Temporal and spatial heterogeneity of host response to SARS-CoV-2 pulmonary infection. Nat Commun 2020;11(1):6319. Doi: 10.1038/s41467-020-20139-7.

55. Fajgenbaum DC., June CH. Cytokine Storm. N Engl J Med 2020;383(23):2255-73. Doi: 10.1056/NEJMra2026131.

56. Nienhold R., Ciani Y., Koelzer VH., Tzankov A., Haslbauer JD., Menter T., et al. Two distinct immunopathological profiles in autopsy lungs of COVID-19. Nat Commun 2020;11(1):5086. Doi: 10.1038/s41467-020-18854-2.

57. Stanetty P., Hattinger G., Schnürch M., Mihovilovic MD. Novel and Efficient Access to Phenylamino-pyrimidine Type Protein Kinase C Inhibitors Utilizing a Negishi Cross-Coupling Strategy. J Org Chem 2005;70(13):5215-20. Doi: 10.1021/jo0505223.

58. Kannaiyan R., Shanmugam MK., Sethi G. Molecular targets of celastrol derived from Thunder of God Vine: Potential role in the treatment of inflammatory disorders and cancer. Cancer Lett 2011;303(1):9-20. Doi: https://doi.org/10.1016/j.canlet.2010.10.025.

59. Luo Y., Shoemaker AR., Liu X., Woods KW., Thomas SA., de Jong R., et al. Potent and selective inhibitors of Akt kinases slow the progress of tumors \&lt;em\&gt;in vivo\&lt;/em\&gt; Mol Cancer Ther 2005;4(6):977 LP - 986. Doi: 10.1158/1535-7163.MCT-05-0005.

60. Kantarjian H., Jabbour E., Grimley J., Kirkpatrick P. Dasatinib. Nat Rev Drug Discov 2006;5(9):717-8. Doi: $10.1038 / \mathrm{nrd} 2135$.

61. Wang J., Erazo T., Ferguson FM., Buckley DL., Gomez N., Muñoz-Guardiola P., et al. Structural and Atropisomeric Factors Governing the Selectivity of Pyrimido-benzodiazipinones as Inhibitors of Kinases and Bromodomains. ACS Chem Biol 2018;13(9):2438-48. Doi: 10.1021/acschembio.7b00638.

62. McGuire C., Lee J. Brief Review of Vorinostat. Clin Med Insights Ther 2010;2:CMT.S1102. Doi: 10.4137/CMT.S1102.

63. Kim H-G., Tan L., Weisberg EL., Liu F., Canning P., Choi HG., et al. Discovery of a potent and selective DDR1 receptor tyrosine kinase inhibitor. ACS Chem Biol 2013;8(10):2145-50. Doi: 10.1021/cb400430t.

64. Habtemariam S., Nabavi SF., Berindan-Neagoe I., Cismaru CA., Izadi M., Sureda A., et al. Should we try the antiinflammatory natural product, celastrol, for COVID-19? Phytother Res 2020:1189-90. Doi: 10.1002/ptr.6711.

65. Xian Y., Zhang J., Bian Z., Zhou H., Zhang Z., Lin Z., et al. Bioactive natural compounds against human coronaviruses: a review and perspective. Acta Pharm Sin B 2020;10(7):1163-74. Doi: https://doi.org/10.1016/j.apsb.2020.06.002.

66. Taguchi Y., Turki T. A new advanced in silico drug discovery method for novel coronavirus (SARS-CoV-2) with tensor decomposition-based unsupervised feature extraction. PLoS One 2020;15(9):e0238907.

67. He B., Garmire L. Prediction of repurposed drugs for treating lung injury in COVID-19. ArXiv 2020.

68. Gil C., Ginex T., Maestro I., Nozal V., Barrado-Gil L., Cuesta-Geijo MÁ., et al. COVID-19: Drug Targets and Potential Treatments. J Med Chem 2020;63(21):12359-86. Doi: 10.1021/acs.jmedchem.0c00606.

69. Chang Y-J., Liu CY-Y., Chiang B-L., Chao Y-C., Chen C-C. Induction of IL-8 release in lung cells via activator protein-1 by recombinant baculovirus displaying severe acute respiratory syndrome-coronavirus spike proteins: identification of two functional regions. J Immunol 2004;173(12):7602-14. Doi: 10.4049/jimmunol.173.12.7602.

70. Lin L., Lu L., Cao W., Li T. Hypothesis for potential pathogenesis of SARS-CoV-2 infection-a review of immune changes in patients with viral pneumonia. Emerg Microbes Infect 2020;9(1):727-32. Doi: 10.1080/22221751.2020.1746199.

71. Tse GM-K., To K-F., Chan PK-S., Lo AWI., Ng K-C., Wu A., et al. Pulmonary pathological features in coronavirus associated severe acute respiratory syndrome (SARS). J Clin Pathol 2004;57(3):260-5. Doi: 10.1136/jcp.2003.013276.

72. Rauzi F., Kirkby NS., Edin ML., Whiteford J., Zeldin DC., Mitchell JA., et al. Aspirin inhibits the production of proangiogenic 15(S)-HETE by platelet cyclooxygenase-1. FASEB J 2016. Doi: 10.1096/fj.201600530R.

73. Cascão R., Fonseca JE., Moita LF. Celastrol: A Spectrum of Treatment Opportunities in Chronic Diseases. Front Med 2017;4:69. Doi: 10.3389/fmed.2017.00069.

74. Yu J-S., Tseng C-K., Lin C-K., Hsu Y-C., Wu Y-H., Hsieh C-L., et al. Celastrol inhibits dengue virus replication via upregulating type I interferon and downstream interferon-stimulated responses. Antiviral Res 2017;137:49-57. Doi: 10.1016/j.antiviral.2016.11.010.

75. Tisoncik JR., Korth MJ., Simmons CP., Farrar J., Martin TR., Katze MG. Into the Eye of the Cytokine Storm. Microbiol Mol Biol Rev 2012;76(1):16 LP - 32. Doi: 10.1128/MMBR.05015-11. 
bioRxiv preprint doi: https://doi.org/10.1101/2021.04.20.439992; this version posted April 20, 2021. The copyright holder for this preprint (which was not certified by peer review) is the author/funder. All rights reserved. No reuse allowed without permission.

76. Demedts IK., Bracke KR., Van Pottelberge G., Testelmans D., Verleden GM., Vermassen FE., et al. Accumulation of dendritic cells and increased CCL20 levels in the airways of patients with chronic obstructive pulmonary disease. Am J Respir Crit Care Med 2007;175(10):998-1005. Doi: 10.1164/rccm.200608-11130C.

77. $\quad$ Liang M., Jiang Z., Huang Q., Liu L., Xue Y., Zhu X., et al. Clinical Association of Chemokine (C-X-C motif) Ligand 1 (CXCL1) with Interstitial Pneumonia with Autoimmune Features (IPAF). Sci Rep 2016;6(1):38949. Doi: 10.1038/srep38949.

78. Wang H., Ahn KS., Alharbi SA., Shair OH., Arfuso F., Sethi G., et al. Celastrol Alleviates Gamma Irradiation-Induced Damage by Modulating Diverse Inflammatory Mediators. Int J Mol Sci 2020;21(3):1084. Doi: 10.3390/ijms21031084.

79. Gupta S., Singh AK., Kushwaha PP., Prajapati KS., Shuaib M., Senapati S., et al. Identification of potential natural inhibitors of SARS-CoV2 main protease by molecular docking and simulation studies. J Biomol Struct Dyn 2020:1-12. Doi: 10.1080/07391102.2020.1776157.

80. Caruso F., Singh M., Belli S., Berinato M., Rossi M. Interrelated Mechanism by Which the Methide Quinone Celastrol, Obtained from the Roots of Tripterygium wilfordii, Inhibits Main Protease 3CL(pro) of COVID-19 and Acts as Superoxide Radical Scavenger. Int J Mol Sci 2020;21(23). Doi: 10.3390/ijms21239266.

81. Ryu YB., Park S-J., Kim YM., Lee J-Y., Seo WD., Chang JS., et al. SARS-CoV 3CLpro inhibitory effects of quinonemethide triterpenes from Tripterygium regelii. Bioorg Med Chem Lett 2010;20(6):1873-1876. Doi: 10.1016/j.bmcl.2010.01.152.

82. Zhang D., Chen Z., Hu C., Yan S., Li Z., Lian B., et al. Celastrol binds to its target protein via specific noncovalent interactions and reversible covalent bonds. Chem Commun 2018;54(91):12871-4. Doi: 10.1039/C8CC06140H.

83. Sreeramulu S., Gande SL., Göbel M., Schwalbe H. Molecular Mechanism of Inhibition of the Human Protein Complex Hsp90-Cdc37, a Kinome Chaperone-Cochaperone, by Triterpene Celastrol. Angew Chemie Int Ed 2009;48(32):5853-5. Doi: https://doi.org/10.1002/anie.200900929.

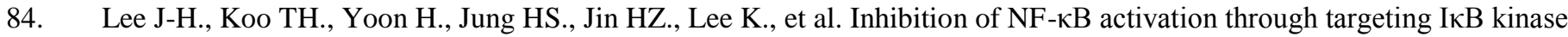
by celastrol, a quinone methide triterpenoid. Biochem Pharmacol 2006;72(10):1311-21. Doi: https://doi.org/10.1016/j.bcp.2006.08.014.

85. Caruso F., Rossi M., Pedersen JZ., Incerpi S. Computational studies reveal mechanism by which quinone derivatives can inhibit SARS-CoV-2. Study of embelin and two therapeutic compounds of interest, methyl prednisolone and dexamethasone. J Infect Public Health 2020;13(12):1868-77. Doi: 10.1016/j.jiph.2020.09.015.

86. Shen B., Yi X., Sun Y., Bi X., Du J., Zhang C., et al. Proteomic and Metabolomic Characterization of COVID-19 Patient Sera. Cell 2020. Doi: 10.1016/j.cell.2020.05.032.

87. Tomazini BM., Maia IS., Cavalcanti AB., Berwanger O., Rosa RG., Veiga VC., et al. Effect of Dexamethasone on Days Alive and Ventilator-Free in Patients with Moderate or Severe Acute Respiratory Distress Syndrome and COVID-19: The CoDEX Randomized Clinical Trial. JAMA - J Am Med Assoc 2020. Doi: 10.1001/jama.2020.17021.

88. Khalili N., Karimi A., Moradi M-T., Shirzad H. In vitro immunomodulatory activity of celastrol against influenza A virus infection. Immunopharmacol Immunotoxicol 2018;40(3):250-5. Doi: 10.1080/08923973.2018.1440591.

89. Narayan V., Ravindra KC., Chiaro C., Cary D., Aggarwal BB., Henderson AJ., et al. Celastrol inhibits Tat-mediated human immunodeficiency virus (HIV) transcription and replication. J Mol Biol 2011;410(5):972-83. Doi: 10.1016/j.jmb.2011.04.013

90. Fraga-Silva TF de C., Maruyama SR., Sorgi CA., Russo EM de S., Fernandes APM., de Barros Cardoso CR., et al. COVID-19: Integrating the Complexity of Systemic and Pulmonary Immunopathology to Identify Biomarkers for Different Outcomes. Front Immunol 2020;11:599736. Doi: 10.3389/fimmu.2020.599736.

91. Venkatesha SH., Yu H., Rajaiah R., Tong L., Moudgil KD. Celastrus-derived celastrol suppresses autoimmune arthritis by modulating antigen-induced cellular and humoral effector responses. J Biol Chem 2011;286(17):15138-46. Doi: 10.1074/jbc.M111.226365.

92. Chiang K-C., Tsui K-H., Chung L-C., Yeh C-N., Chen W-T., Chang P-L., et al. Celastrol blocks interleukin-6 gene expression via downregulation of NF- $\mathrm{BB}$ in prostate carcinoma cells. PLoS One 2014;9(3):e93151. Doi: 10.1371/journal.pone.0093151.

93. Kim DH., Shin EK., Kim YH., Lee BW., Jun J-G., Park JHY., et al. Suppression of inflammatory responses by celastrol, a quinone methide triterpenoid isolated from Celastrus regelii. Eur J Clin Invest 2009;39(9):819-27. Doi: https://doi.org/10.1111/j.1365-2362.2009.02186.x.

94. Majumder S., Zappulla F., Silbart LK. Mycoplasma gallisepticum lipid associated membrane proteins up-regulate inflammatory genes in chicken tracheal epithelial cells via TLR-2 ligation through an NF- $\mathrm{B}$ dependent pathway. PLoS One 2014;9(11):e112796. Doi: 10.1371/journal.pone.0112796.

95. Ye S., Luo W., Khan ZA., Wu G., Xuan L., Shan P., et al. Celastrol Attenuates Angiotensin II-Induced Cardiac Remodeling by Targeting STAT3. Circ Res 2020;126(8):1007-23. Doi: 10.1161/CIRCRESAHA.119.315861.

96. Nie Y., Fu C., Zhang H., Zhang M., Xie H., Tong X., et al. Celastrol slows the progression of early diabetic nephropathy in rats via the PI3K/AKT pathway. BMC Complement Med Ther 2020;20(1):321. Doi: 10.1186/s12906-020-03050-y.

97. Liu J., Lee J., Salazar Hernandez MA., Mazitschek R., Ozcan U. Treatment of Obesity with Celastrol. Cell 2015;161(5):999-1011. Doi: 10.1016/j.cell.2015.05.011. 
bioRxiv preprint doi: https://doi.org/10.1101/2021.04.20.439992; this version posted April 20, 2021. The copyright holder for this preprint (which was not certified by peer review) is the author/funder. All rights reserved. No reuse allowed without permission.

98. Zhu Y., Wan N., Shan X., Deng G., Xu Q., Ye H., et al. Celastrol targets adenylyl cyclase-associated protein 1 to reduce macrophages-mediated inflammation and ameliorates high fat diet-induced metabolic syndrome in mice. Acta Pharm Sin B 2020. Doi: https://doi.org/10.1016/j.apsb.2020.12.008.

99. Allen SD., Liu Y-G., Kim T., Bobbala S., Yi S., Zhang X., et al. Celastrol-loaded PEG-b-PPS nanocarriers as an antiinflammatory treatment for atherosclerosis. Biomater Sci 2019;7(2):657-68. Doi: 10.1039/C8BM01224E.

100. Liu J., Liu J., Wang H., Bai M. Protective effect of celastrol for burn-induced acute lung injury in rats. Int J Clin Exp Pathol 2019;12(2):576-83.

101. Yu Y., Koehn CD., Yue Y., Li S., Thiele GM., Hearth-Holmes MP., et al. Celastrol Inhibits Inflammatory StimuliInduced Neutrophil Extracellular Trap Formation. Curr Mol Med 2015:401-10. Doi: http://dx.doi.org/10.2174/1566524015666150505160743.

102. Wu C., Jin H-Z., Shu D., Li F., He C-X., Qiao J., et al. Efficacy and safety of Tripterygium wilfordii hook F versus acitretin in moderate to severe psoriasis vulgaris: a randomized clinical trial. Chin Med J (Engl) 2015;128(4):443-9. Doi: 10.4103/0366-6999.151069.

103. Fang Z., He D., Yu B., Liu F., Zuo J., Li Y., et al. High-Throughput Study of the Effects of Celastrol on Activated Fibroblast-Like Synoviocytes from Patients with Rheumatoid Arthritis. Genes (Basel) 2017;8(9). Doi: 10.3390/genes8090221.

104. Li J., Hao J. Treatment of Neurodegenerative Diseases with Bioactive Components of Tripterygium wilfordii. Am J Chin Med 2019;47(4):769-85. Doi: 10.1142/S0192415X1950040X.

105. Li H-Y., Zhang J., Sun L-L., Li B-H., Gao H-L., Xie T., et al. Celastrol induces apoptosis and autophagy via the ROS/JNK signaling pathway in human osteosarcoma cells: an in vitro and in vivo study. Cell Death Dis $2015 ; 6$ :e1604. Doi: $10.1038 /$ cddis.2014.543.

106. Pinna GF., Fiorucci M., Reimund J-M., Taquet N., Arondel Y., Muller CD. Celastrol inhibits pro-inflammatory cytokine secretion in Crohn's disease biopsies. Biochem Biophys Res Commun 2004;322(3):778-86. Doi: https://doi.org/10.1016/j.bbrc.2004.07.186.

107. Wu J., Hong C., Pan H., Yang Q., Mei Y., Yang QPD and H. Medicinal Compound Celastrol As a Potential Clinical Anticancer Drug: Lessons Learned From Preclinical Studies. Clin Cancer Drugs 2016:63-73. Doi: http://dx.doi.org/10.2174/2212697X03666160112001739.

108. Zhang T., Hamza A., Cao X., Wang B., Yu S., Zhan C-G., et al. A novel Hsp90 inhibitor to disrupt Hsp90/Cdc37 complex against pancreatic cancer cells. Mol Cancer Ther 2008;7(1):162 LP - 170. Doi: 10.1158/1535-7163.MCT-07-0484.

109. Wang Z., Chen D., Wang Z. Effects of diclofenac on the pharmacokinetics of celastrol in rats and its transport. Pharm Biol 2018;56(1):269-74. Doi: 10.1080/13880209.2018.1459740.

110. Hu W., Wang L., Du G., Guan Q., Dong T., Song L., et al. Effects of Microbiota on the Treatment of Obesity with the Natural Product Celastrol in Rats. Diabetes Metab J 2020;44(5):747-63. Doi: 10.4093/dmj.2019.0124.

111. Sanna V., Chamcheu JC., Pala N., Mukhtar H., Sechi M., Siddiqui IA. Nanoencapsulation of natural triterpenoid celastrol for prostate cancer treatment. Int J Nanomedicine 2015;10:6835-46. Doi: 10.2147/IJN.S93752.

112. Wolfram J., Suri K., Huang Y., Molinaro R., Borsoi C., Scott B., et al. Evaluation of anticancer activity of celastrol liposomes in prostate cancer cells. J Microencapsul 2014;31(5):501-7. Doi: 10.3109/02652048.2013.879932.

113. Niemelä E., Desai D., Nkizinkiko Y., Eriksson JE., Rosenholm JM. Sugar-decorated mesoporous silica nanoparticles as delivery vehicles for the poorly soluble drug celastrol enables targeted induction of apoptosis in cancer cells. Eur J Pharm Biopharm Off J Arbeitsgemeinschaft Fur Pharm Verfahrenstechnik eV 2015;96:11-21. Doi: 10.1016/j.ejpb.2015.07.009.

114. Bassanini I., Parapini S., Ferrandi EE., Gabriele E., Basilico N., Taramelli D., et al. Design, Synthesis and In Vitro Investigation of Novel Basic Celastrol Carboxamides as Bio-Inspired Leishmanicidal Agents Endowed with Inhibitory Activity against Leishmania Hsp90. Biomolecules 2021;11(1):56. Doi: 10.3390/biom11010056. 


\section{Figure legends}

Figure 1. Assessment of gene signature in SARS-CoV-2-infected human bronchial epithelial cells (NHBE) for drug repurposing to treat Covid-19. (a) Enriched biological pathways associated with Covid19 from Reactome annotations ( $\left.p_{a d j}<0.05\right)$ from DEGs identified in NHBE-infected cells transcriptome data. The genes that enriched each pathway (left) are indicated together with statistical results and pathway description (right). (b) Heatmap of genes from the 50 best-ranked drug signatures that reversed the genetic signature of SARS-CoV-2-infected NHBE cells in decreasing order of $Q_{\text {score }}$. The signature map annotations are related to up- and down-regulated genes, and cell lines are indicated in different colors. (c) Drugs in decreasing order of $Q_{\text {score }}$ following the output of $\mathrm{L}_{1000 \mathrm{CDS}^{2}}$. A dashed line indicates the mean $Q_{\text {score }}(0.26)$ threshold. Equal $Q_{\text {score }}$ values are displayed over the bars. (d) $B_{\text {score }}$ for each drug, considering the enrichment analysis and drug reverse signature. The dashed line corresponds to the mean $B_{\text {score }}(0.49)$. ${ }^{*}$ Genetic signature that justified the biological validation of celastrol.

Figure 2. Docking analysis of molecular interactions between viral targets and drugs capable of reversing SARS-CoV-2 genetic signature. (a) Representative structures of the SARS-CoV-2 molecular targets ( $\mathrm{M}^{\text {pro }}$, RBD, and RdRp), where atoms are represented as lines and secondary structures as a cartoon with helices highlighted in magenta and sheets in yellow. Colored line circles (red - M ${ }^{\text {pro; }}$ RDB1 - blue; RBD2 - orange; RdRp - green) indicate the binding sites used for docking related to known inhibition of critical regions from each viral target ${ }^{19,24-27}$. (b) Boxplots illustrate the affinity binding energies $\left(\mathrm{kcal}^{\mathrm{mol}} \mathrm{m}^{-1}\right)$ obtained from docking analysis between several structural conformations of 39 drugs and each viral site $\left(\mathrm{M}^{\text {pro }}=83\right.$; $\mathrm{RDB} 1=10 ; \mathrm{RBD} 2=10$; and $\mathrm{RdRp}=10$ structures). The reverser drugs were sorted based on decreasing order of $Q_{\text {score }}$ that indicated their potential to revert the genetic signature of SARS-CoV-2 infection. Dotted lines indicate median affinity binding energies defined for each viral target $\left(\mathrm{M}^{\mathrm{pro}}=-7.3 ; \mathrm{RDB} 1=-6.2 ; \mathrm{RBD} 2=-6.7\right.$; and $\mathrm{RdRp}=-7.2 \mathrm{kcal} . \mathrm{mol}^{-1}$ ) considering all investigated drugs.

Figure 3. Detailed chemical interactions between the best-ranked drugs and inhibition sites of SARSCoV-2 molecular targets. 2D target-drug interaction diagrams for the best structural configurations of viral molecular targets was determined using the Discovery Studio ${ }^{\circledR}$ software (version-2020). Celastrol had the most attractive $\Delta G_{\text {bind }}$ median values of affinity energy to three targets ( $\mathrm{M}^{\mathrm{pro}}$, RBD1, and RBD2) and WZ-4145 to one (RdRp). The distance between the B-ring C6 and the sulfur atom of the Cys145 residue, which may be related to a possible Michael adduct formation for the best energy poses in each $\mathrm{M}^{\text {pro }}$ structure, ranged from 0.43 to $1.33 \mathrm{~nm}$, with average value of $0.63 \mathrm{~nm}$ (black dashed line).

Figure 4. Celastrol suppresses SARS-CoV-2 in vitro propagation in non-human and human cell lines. RTPCR quantification of SARS-CoV-2 RNA in supernatants from the infected cell lines (a) Vero CCL-81 (b) Vero CCL-81-ACE2, (c) Caco-2, and (d) Calu-3 treated with celastrol at concentrations of 125, 250, 500, and $1000 \mathrm{nM}$. DMSO solution (0.05\%; vehicle) was used as negative control. Cells were infected using MOI = 1.0 for 2 hours and then treated with celastrol for 48 hours. The detection levels of SARS-CoV-2 RNA were performed in the supernatants of cultures and expressed in viral load using a standard curve described in the Material and Methods section. Statistical differences between celastrol treatments and the negative control were analyzed by ANOVA followed by Tukey's post-test. The significance levels were indicated as $* \mathrm{P}<$ $0.05, * * \mathrm{P}<0.01, * * * \mathrm{P}<0.001$, and $* * * * \mathrm{P}<0.0001$.

Figure 5. Celastrol does not affect cell viability. AlamarBlue assay was used to measure the potential cytotoxic effect of celastrol. The monkey cell lines (a) Vero CCL-81 and (b) Vero CCL-81-ACE2, and the human cell lines (c) Caco-2 and (d) Calu-3 were treated with celastrol at 250 and $1000 \mathrm{nM}$, for 48 hours. DMSO solutions at $0.05 \%$ and $5.0 \%$ were used as the negative and positive controls of cell death, respectively. Statistical analysis was performed using ANOVA followed by the Tukey's post-test to compare treatment with celastrol and 5.0\% DMSO. ****P $<0.0001$. 
Figure 6. Celastrol inhibits IL-6 production in SARS-CoV-2-infected human cell lines. ELISA quantification of IL-6 in the culture supernatants from the human cell lines (a) Caco-2 and (b) Calu-3, infected with SARS-CoV-2 (MOI = 1.0) for 2 hours and then treated with celastrol for 48 hours. DMSO solution at $0.05 \%$ (vehicle) was used as the negative control. Statistical differences between celastrol treatment and control were analyzed by ANOVA followed by Tukey's post-test. The significance levels were indicated as $* * \mathrm{P}<0.01, * * * \mathrm{P}<0.001$, and $* * * * \mathrm{P}<0.0001$. The results are expressed as mean \pm standard error of the mean (SEM) of IL-6 (pg/mL) and are representative of two independent experiments with Caco-2 cells and one experiment with Calu-3 cells. 
bioRxiv preprint doi: https://doi.org/10.1101/2021.04.20.439992; this version posted April 20, 2021. The copyright holder for this preprint (which was not certified by peer review) is the author/funder. All rights reserved. No reuse allowed without permission.

\section{Table}

Table 1. Primers/probe sequences for detection of SARS-CoV-2 genome and housekeeping gene ${ }^{50}$

\begin{tabular}{llr}
\hline & Primer & Sequence \\
\hline \multirow{2}{*}{ N2 } & Forward & \\
& Reverse & 5'-TTA CAA ACA TTG GCC GCA AA-3' \\
& Probe & 5'-GCG CGA CAT TCC GAA GAA-3' \\
& Forward & 5'-FAM-ACA ATT TGC CCC CAG CGC TTC AG-BHQ1-3' \\
\multirow{2}{*}{ RNAse-P } & Reverse & 5'-AGA TTT GGA CCT GCG AGC G-3' \\
& Probe & 5'-GAG CGG CTG TCT CCA CAA GT-3' \\
& & 5'-FAM - TTC TGA CCT GAA GGC TCT GCG CG - BHQ-1-3' \\
\hline
\end{tabular}


bioRxiv preprint doi: https://doi.org/10.1101/2021.04.20.439992; this version posted April 20, 2021. The copyright holder for this preprint (which was not certified by peer review) is the author/funder. All rights reserved. No reuse allowed without permission.

Figure 1 - Fuzo et al.

a Enriched reactome pathways of SARS-CoV-2-infected NHBE cells

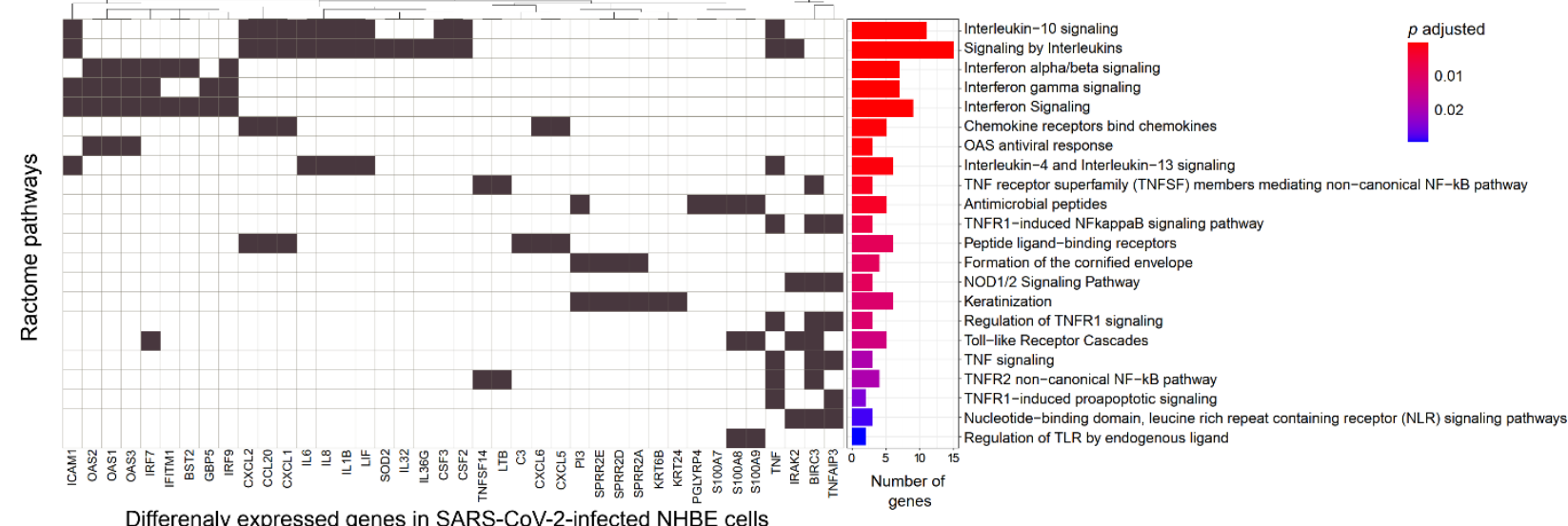

b Differenaly expressed genes in SARS-CoV-2-infected NHBE cells

b Differential Expression: Human cell lines:

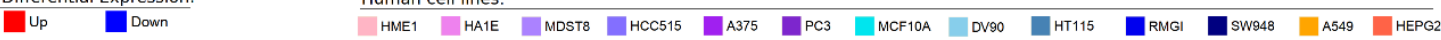
Human cell lines

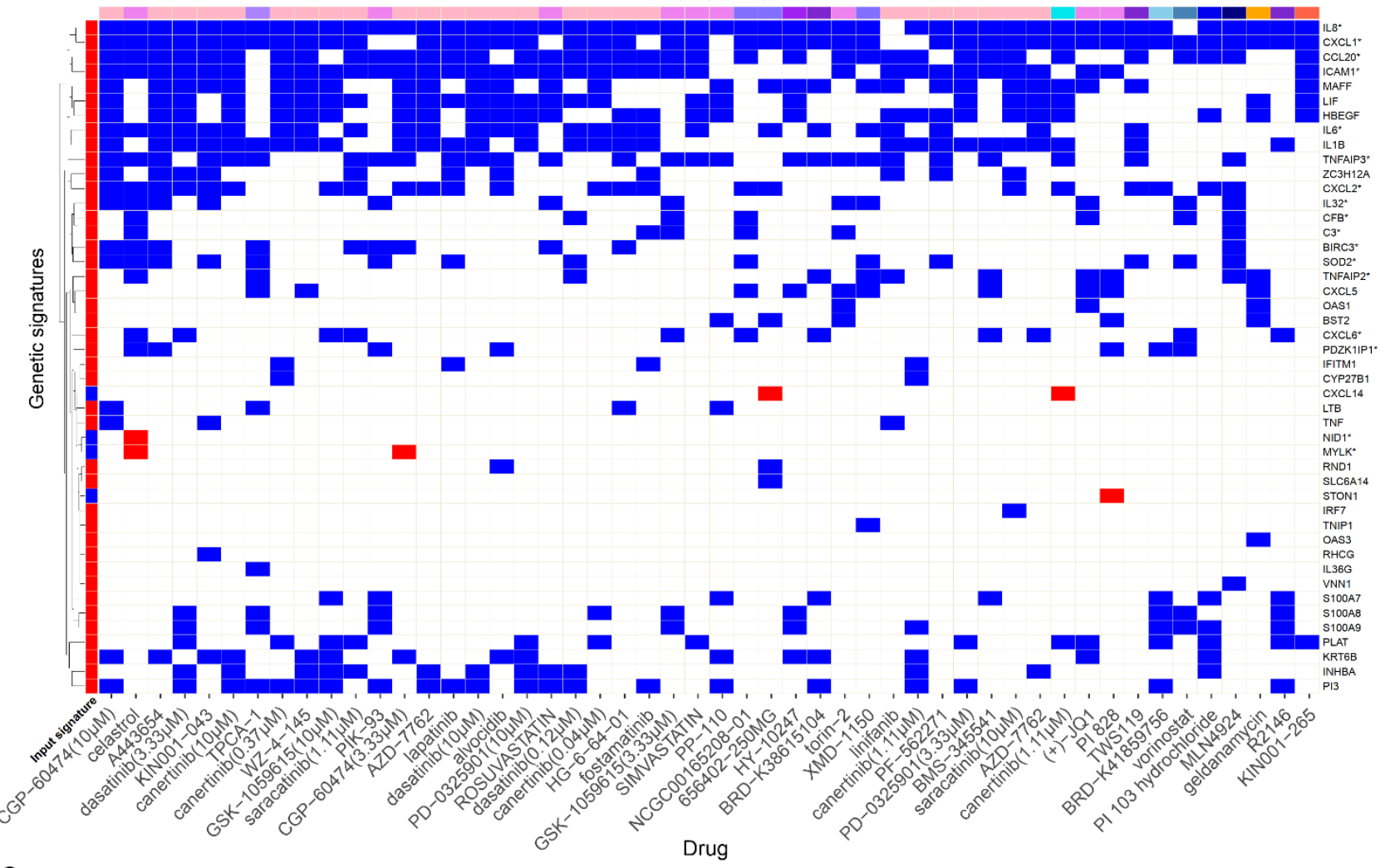

C

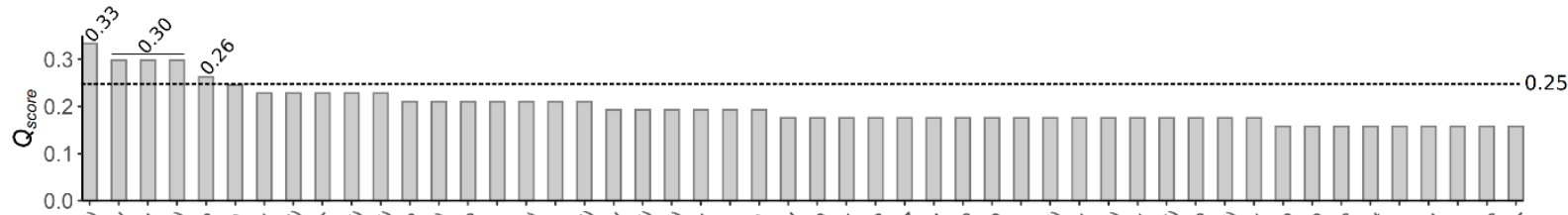

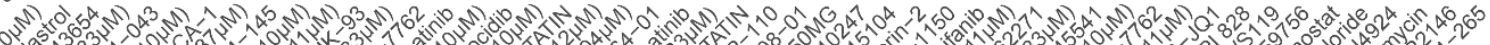

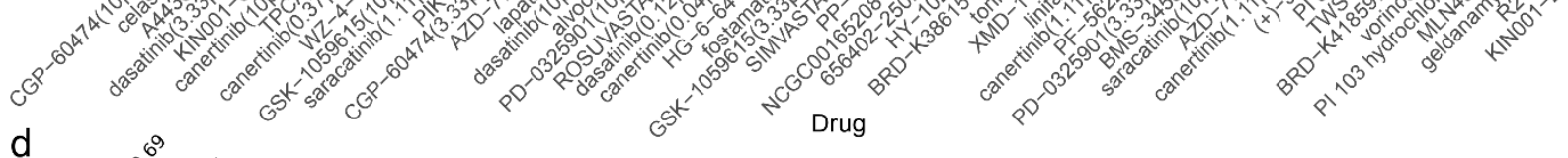

d

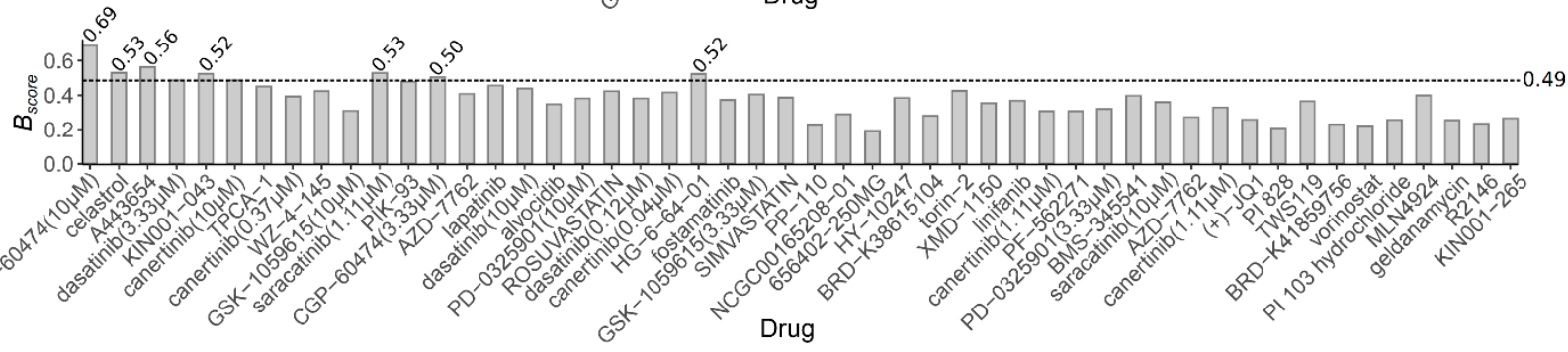


bioRxiv preprint doi: https://doi.org/10.1101/2021.04 20.439992; this version posted April 20, 2021. The copyright holder for this preprint (which was not certified by peer review) is the author/funder. All rights reserved. No reuse allowed without permission.

Figure 2 - Fuzo et al.

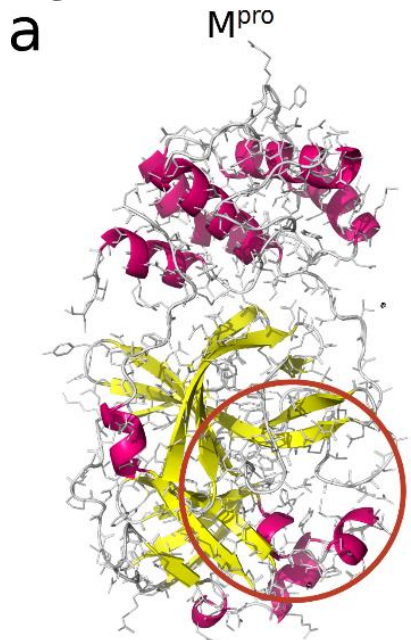

RBD

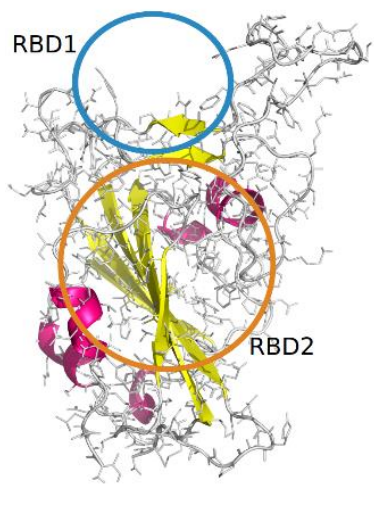

$\operatorname{RdRp}$

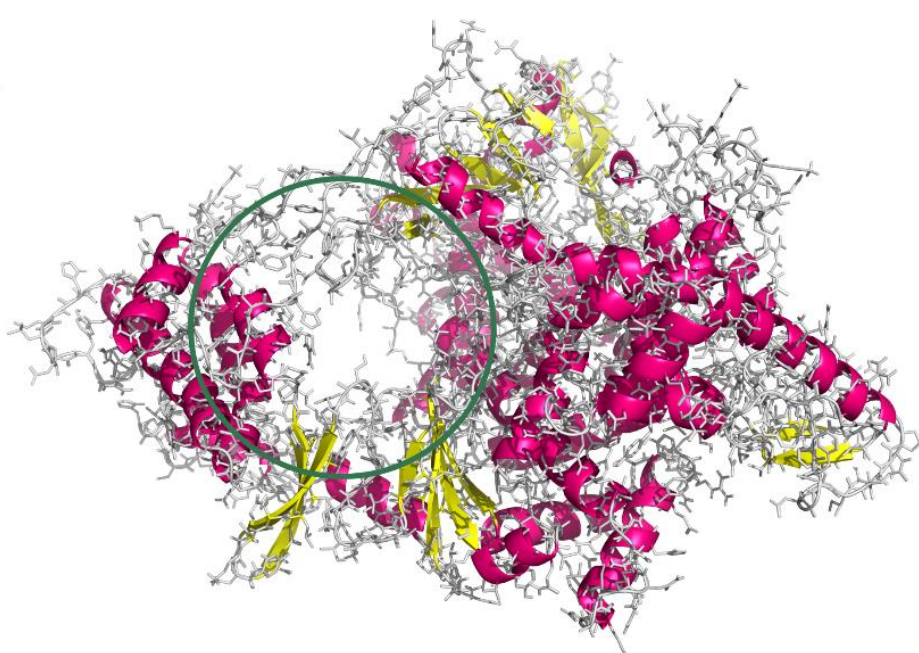

b MPro RBD1 RBD2 ORdRp

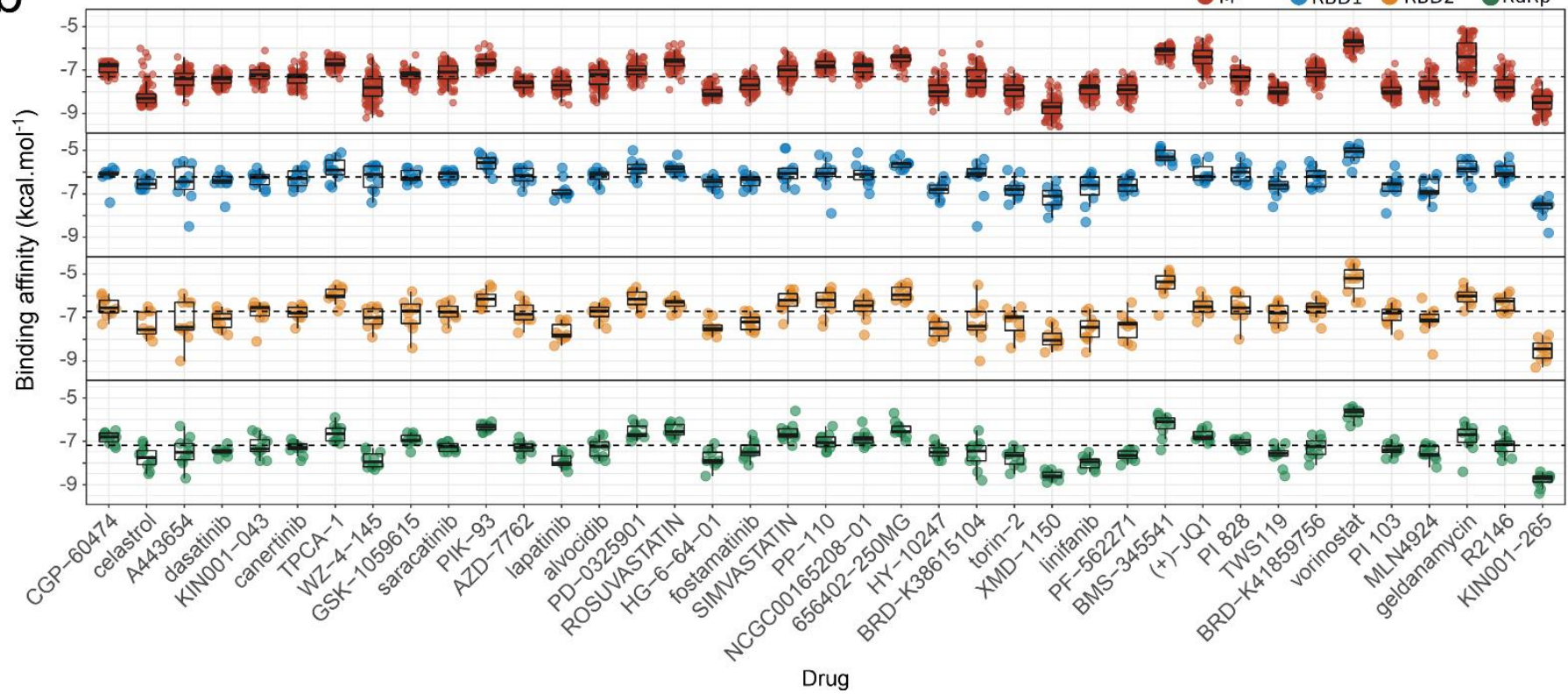


bioRxiv preprint doi: https://doi.org/10.1101/2021.04.20.439992; this version posted April 20, 2021. The copyright holder for this preprint (which was not certified by peer review) is the author/funder. All rights reserved. No reuse allowed without permission.

Figure 3 - Fuzo et al.
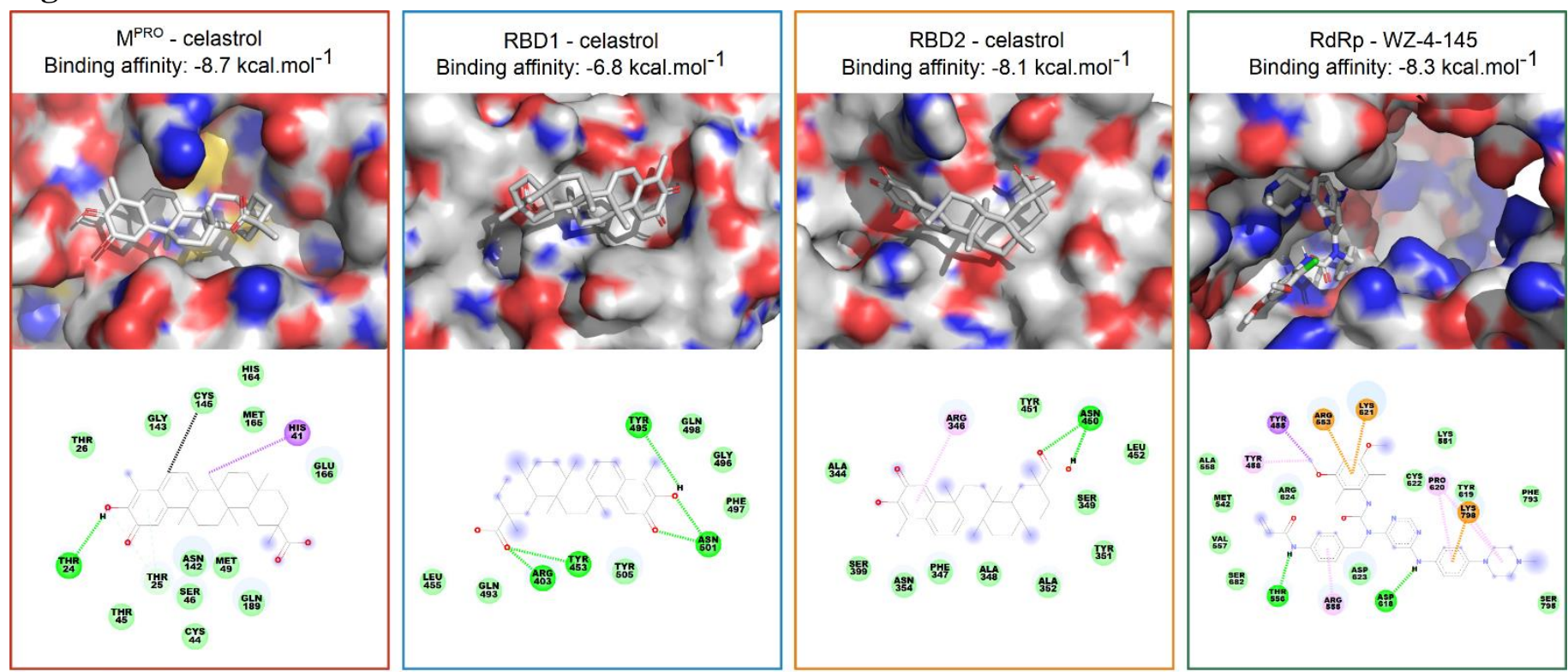

Interactions:

$\square$ van der Waals

$\square$ Carbon Hydrogen Bond

$\square$ Pi-Anion

$\square$ Pi-Sigma

Pi-Pi Stacked

$\square$ Pi-Pi T-shaped

$\square$ Alkyl

Conventional Hydrogen Bond

Pi-Cation

$\square$ Pi-Donor Hydrogen Bond

$\square$ Pi-Alkyl 
bioRxiv preprint doi: https://doi.org/10.1101/2021.04.20.439992; this version posted April 20, 2021. The copyright holder for this preprint (which was not certified by peer review) is the author/funder. All rights reserved. No reuse allowed without permission.

Figure 4 - Fuzo et al.
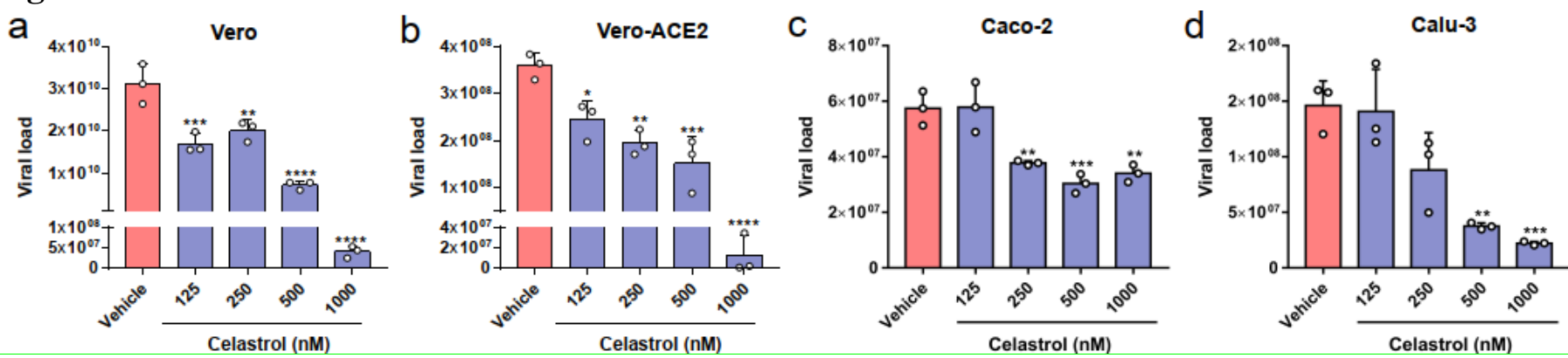

(which was not certified by peer review) is the author/funder. All rights reserved. No reuse allowed without permission.

Figure 5 - Fuzo et al.
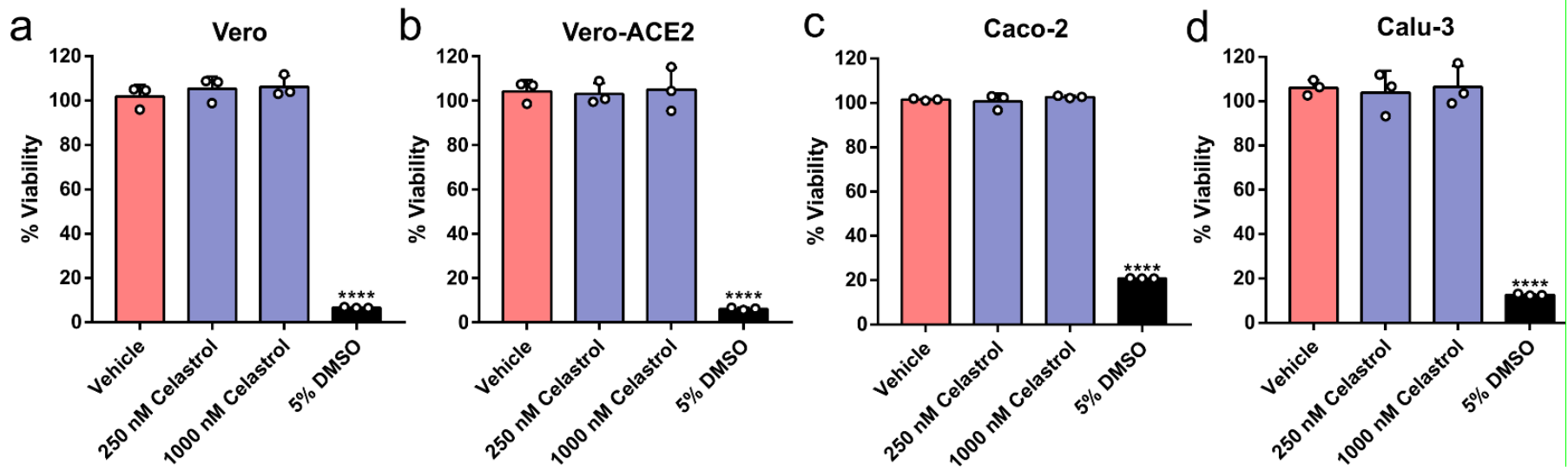
bioRxiv preprint doi: https://doi.org/10.1101/2021.04.20.439992; this version posted April 20, 2021. The copyright holder for this preprint (which was not certified by peer review) is the author/funder. All rights reserved. No reuse allowed without permission.

Figure 6 - Fuzo et al.
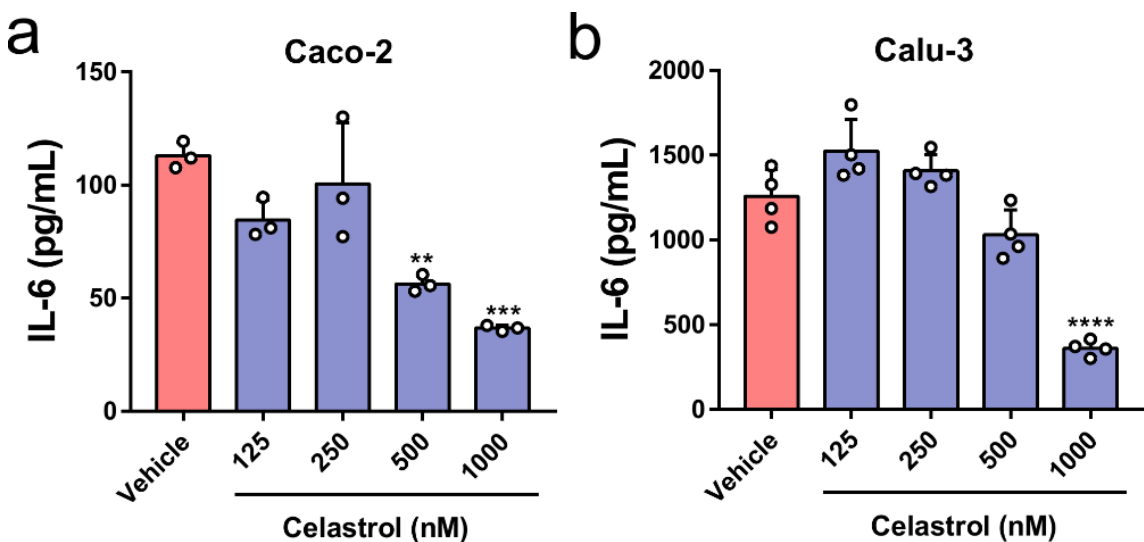